Plant Tissue Cult. \& Biotech. 29(2): 219-230, 2019 (December)

CBangladesh Assoc. for Plant Tissue Culture \& Biotechnology

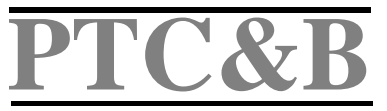

\title{
Effects of Cucumber Mosaic Virus on Cellular Components, Host Physiology and Yield of Chilli
}

\author{
Md. Siddiqur Rahman*, K. Jahan, Ashfak Ahmed Sabuz ${ }^{1}$ and A. M. \\ Akanda $^{2}$
}

Plant Pathology Division, Bangladesh Agricultural Research Institute, Joydebpur, Gazipur-1701, Bangladesh

Key words: Cucumber mosaic virus, Chilli, Chlorophyll, $\beta$-carotene

\begin{abstract}
Alteration of cellular components and host physiology due to five biotypes of Cucumber mosaic virus (CMV) were investigated to know the effects on ultimate growth and yield of chilli. Severe reduction of cellular components like chlorophyll-a (59.31\%), chlorophyll-b $(68.40 \%)$, total chlorophyll $(63.20 \%)$ and $\beta$-carotene $(51.14 \%)$ were observed in plant infected by mosaic and stunting (MoS) as compared to healthy plant. The ratio of RNA to DNA was increased in the infected leaves. The reduction of photosynthesis rate was found 6.32 to $17.10 \%$ in CMV infected plants as compared to healthy plants. Stomatal conductance and inter cellular $\mathrm{CO}_{2}$ was found lower in $\mathrm{CMV}$ infected plats. Considerable yield reduction $(28.80$ to $78.11 \%$.) was found infected with five symptomatic isolate of $\mathrm{CMV}$. The present findings indicate that multiplication of virus particles in the infected cells alter the biochemical compounds of cells that disrupt the physiological process which affect the growth and yield of chilli.
\end{abstract}

\section{Introduction}

Cucumber mosaic virus (CMV) is considered as the most important viral disease of chilli in Bangladesh. It is the type member of the genus Cucumovirus under the family Bromoviridae, is a single-stranded, positive-sense RNA plant virus (Palukaitis and Garcia-Arenal 2003). CMV infects more than 1200 plant species and induces the typical mosaic symptoms including monocotyledons and dicotyledons (Kim et al. 2011). It spreads naturally by more than 60 aphid species in a non-persistent manner (Palukaitis et al. 1992) and reduced yield by 33 to $60 \%$ in chilli (Montasser et al. 1998). CMV infection

*Author for correspondence: <mdsidiqurrahman@yahoo.com>. ${ }^{1}$ Postharvest Technology Division, BARI, Bangladesh. 2Department of Plant Pathology, BSMRAU, Bangladesh.

DOI: https://doi.org/10.3329/ptcb.v29i2.44511 
causes mild to severe mosaic, vein bending, vein clearing, puckering of leaves, stunting with or without leaf deformation, yellow discoloration, shoestring, top necrosis, necrotic rings spot on leaves and fruits (Fujisawa 1986).

The biochemical alterations of cellular constituents are reported to be directly related to morphological deviation of virus infected plants and the extent of crop loss is largely determined by visible symptoms (Levy and Marco 1982).

Biochemical changes in virus infected plants result in decrease of both quality and quantity of infected crops (Al-Musa 1982). The symptoms specificity and its severity are concerned with the changes of specific cellular components due to virus infection (Sreenivasulu et al. 1989). Multiplication of virus particles in the infected plant cells alters biochemical compounds of cells such as chlorophyll, $\beta$-carotene, organic carbon, nucleic acids etc. and disrupt the physiological process which affect the growth and yield (Fraser 1987). External manifestations of disease symptoms are the results of altered host metabolism. The extent of crop loss is mainly associated with severity of visible symptoms (Sreenivasulu et al. 1989). Greater understanding of the cellular and physiological changes may increase the accuracy of disease loss assessment, which helps to know about the nature of the virus. In Bangladesh, there is no report on the impact of CMV on host physiology and cellular components in chilli, which is important to determine the nature of the host pathogen interaction. Considering the facts stated above, the present investigation was undertaken to determine the effect of CMV infection on cellular components, host physiology as well as plant growth and yield of chilli.

\section{Materials and Methods}

Chilli plants infected with Cucumber mosaic virus showing characteristic symptoms were selected and tagged from the experimental plots of Bangabandhu Sheikh Mujibur Rahman Agricultural University, Gazipur. Leaf samples were collected from the infected plants from the similar position and the similar age showing distinct symptoms to maintain the uniformity of the samples. Leaf samples were also collected from apparently healthy (HL) plants which served as control. The healthy and infected plants were checked for CMV infection using mechanical inoculation and DAS-ELISA methods as described by Clark and Adams (1977). A double beam spectrophotometer (Model No. 1200-20, Hitachi, Japan) was used to measure the absorbance value. Standard analytical methods were followed for determination of contents of different components both for healthy and CMV infected leaf samples as described below.

Chlorophyll content was determined extracting cell sap with $80 \%$ acetone method as proposed by Witham et al. (1986). Also a digital chlorophyll meter (SPAD-502, Minolta Co. Ltd. Japan.) was used to record SPAD from the fully expanded three leaves from each selected plants. For each leaf three reading were taken at basal, middle and terminal part of the leaf. 
$\beta$-carotene was estimated by the formula described by Nagata et al. (1992). One gram of leaf sample was crushed thoroughly and mixed with $10 \mathrm{ml}$ acetone : hexane $(4: 6)$ solution. This sample was centrifuged and optical density of the supernatant was measured using spectrophotometer 663, 645, 505 and $453 \mathrm{\eta m}$. Content of nucleic acids (DNA and RNA) was determined following the method proposed by Spirin (1958).

Leaf photosynthesis and other physiological parameters like stomatal conductance, mesophyll conductance and intercellular $\mathrm{CO}_{2}$ concentration were determined by a portable photosynthesis system (LI-6200, USA). CMV infected plants showing different symptoms along with apparently healthy three replicated plants were selected for data collection. Readings were taken from fully expanded fifth leaf (from the top). Averages of 3 readings were taken from each sample. Data on photosynthesis and other physiological parameters were taken from 14-week-old plants (9 weeks after transplanting) in a clear, bright and sunny day between 11:30 a.m. to 01:30 p.m. Mesophyll conductance was measured by the formula suggested by Kubota and Hamid (1992).

\section{Results and Discussion}

Forty samples were tested by DAS-ELISA against the antisera of Cucumber mosaic virus (CMV), Papaya ring spot virus (PRSV), Zucchini yellow mosaic virus (ZYMV) and Watermelon mosaic virus 2 (WMV-2). The positive reaction of five symptomatic isolates of CMV (Table 1) against the $\mathrm{CMV}$ antisera indicated that the virus produces five distinct symptoms like mild mosaic (Fig. 1A), mosaic (Fig. 1B), mosaic and stunting (Fig. 1C), shoe string (Fig. 1D) and vein banding (Fig. 1E-F). The optical density (OD) value from ELISA reader of the positively reacted samples (Table 1) was in between positive and negative control. It was further confirmed that the samples were infected with CMV. Therefore, the results of ELISA conclusively revealed the presence of CMV with all the five symptoms (Table 1). The present investigation is in conformity with the findings of Zitter and Murphy (2009) and Fujisawa (1986). Kapoor (2012) had detected different CMV biotypes by biological, serological and molecular assay and reported that natural infection of CMV causing mosaic, leaf deformation, and ring spots on leaves and fruits of bell pepper plants. These findings also supported the present study.

Chlorophyll contents of the infected plants in all the cases were found to be decreased significantly in leaves infected with all five symptomatic isolate of CMV as compared to healthy plants (Table 2). The maximum contents of chlorophyll-a (69.58 $\mathrm{mg} / 100 \mathrm{~g})$, chlorophyll-b (44.12 mg/100 g) and total chlorophyll (113.70 mg/100 g) were found in leaves of apparently healthy chilli plants. The degree of reduction varied with the symptomatic isolates of the virus. Severe reduction of chlorophyll-a (59.31\%), chlorophyll-b (68.40\%) and total chlorophyll (63.20\%) was observed in mosaic and stunting (MoS) infected chilli leaves (Fig. 2). The lowest reduction of all chlorophyll partitions was found in MM infected chilli leaves, which was followed by leaves infected with vein banding $(\mathrm{Vb})$. The lowest chlorophyll-a $(28.94 \mathrm{mg} / 100 \mathrm{~g})$ and chlorophyll-b 
(13.53 mg/100 g) content was found in MoS infected leaves. The total chlorophyll content was the lowest $(41.84 \mathrm{mg} / 100 \mathrm{~g}$ ) in leaves infected with MoS, which was followed by Mo $(46.85 \mathrm{mg} / 100 \mathrm{~g}), \mathrm{SS}(61.43 \mathrm{mg} / 100 \mathrm{~g})$ and $\mathrm{Vb}(67.18 \mathrm{mg} / 100 \mathrm{~g})$. The ratio of chlorophyll-a to $b$ was observed to be higher in the entire virus infected leaves as compared to healthy ones (Table 2). The highest ratio (Chl.-a : b) was (2.14) in the leaves infected with the MoS, which was followed by the mosaic (Mo) (2.01), SS (1.96), Vb (1.93) and MM (1.92). It was the lowest (1.58) in healthy chilli leaves.
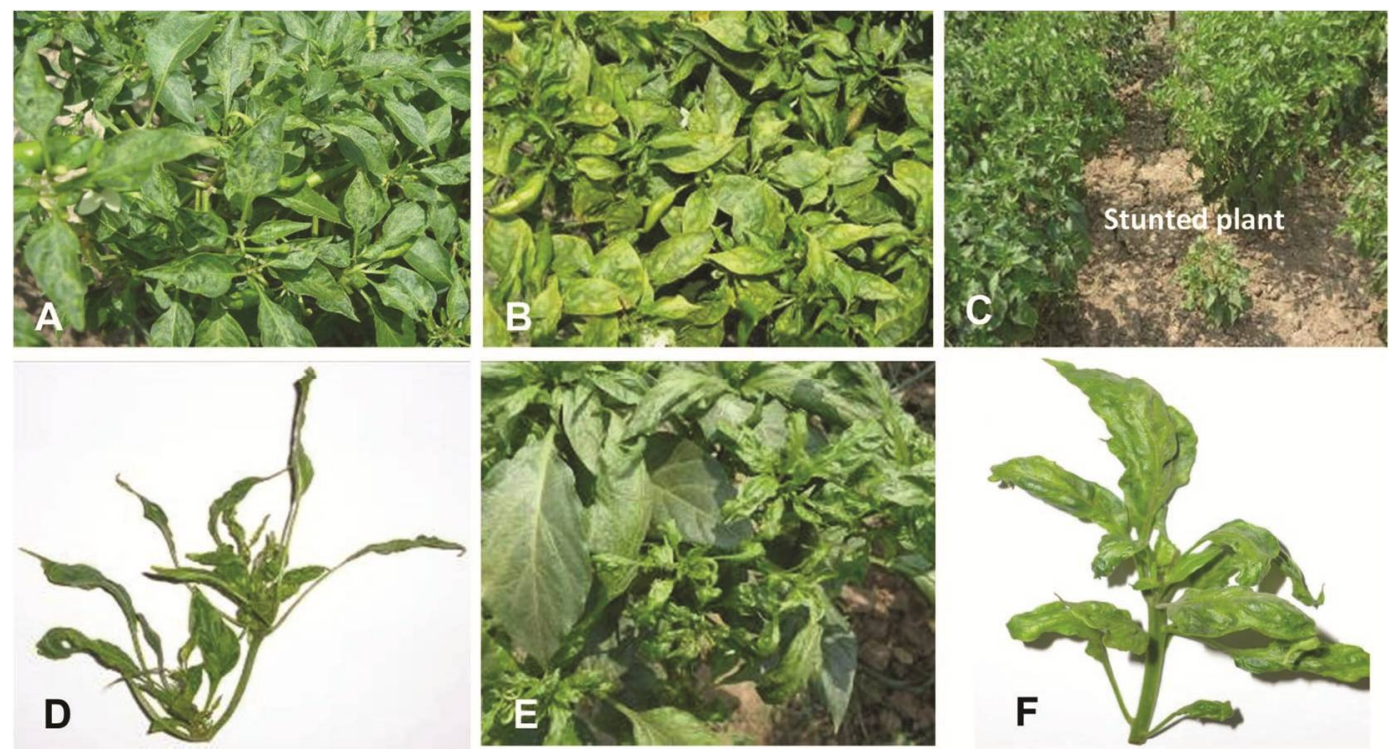

Fig. 1. Five biotypes (symptomatic isolate) of CMV in naturally infected chilli plants. A - Mild mosaic, B - Mosaic, C - Mosaic and stunting, D - Shoe string and E-F - Vein banding symptoms.

The content of $\beta$-carotene $(0.85 \mathrm{mg} / 100 \mathrm{~g})$ was maximum in healthy leaves of chilli. Reduction of $\beta$-carotene was common in all the five biotypes of CMV. The highest reduction of $\beta$-carotene was observed in leaves infected with MoS (51.14\%) followed by Mo (40.53\%), SS (34.89\%), Vb (34.10\%) and mild mosaic (MM) (23.04\%) (Fig. 3). The lowest reduction of $\beta$-carotene contents was found in leaves infected with MM. The inhibition of chlorophyll production or degradation of chlorophyll result in the reduction of chlorophyll content in virus infected plants as reported by Esau (1956). It could be concluded that the virus infected leaves have been attributed two causes-stimulation of chlorophylase which degrades chlorophyll into chlorophyllide and phytol and inhibition of chloroplast development which leads to the development of colour deviations like mosaic, yellowing, chlorosis, etc. The reduction of total chlorophyll was $60 \%$ in case of soyabean infected by Soya bean yellow mosaic virus (Narayanasamy and Palaniswami 1973). Multiplication of virus particles in the infected plant cells alters biochemical compounds of cells such as chlorophyll, $\beta$-carotene, organic carbon, nucleic acids, etc. 
and disrupt the physiological process which affect the growth and yield (Fraser 1987). Haider and Hossain (1994) observed similar trend of reduction in chlorophyll and $\beta$-carotene in the Yellow vein mosaic virus infected okra and CMV infected tomato leaves. The findings of the present study showed that different partition of chlorophyll and $\beta$-carotene reduction followed the similar trend as described earlier. High chlorophyll-a to $b$ ratio indicates more degradation or lower synthesis of chlorophyll-b than chlorophyll-a due to virus infection.

Table 1. Serological (DAS-ELISA) detection of five symptomatic isolate (biotype) of CMV.

\begin{tabular}{|c|c|c|c|c|c|}
\hline \multirow{2}{*}{$\begin{array}{l}\text { Major } \\
\text { symptom }\end{array}$} & \multicolumn{4}{|c|}{ Reaction against the antiserum of } & \multirow{2}{*}{$\begin{array}{c}\text { OD value at } 405 \mathrm{~nm} \\
\text { (Av. of } 5 \text { positive } \\
\text { samples) }\end{array}$} \\
\hline & $\mathrm{CMV}$ & PRSV-P & ZYMV & WMV-2 & \\
\hline - Control & & & & & 0.14 \\
\hline+ Control & & & & & 0.40 \\
\hline Mild mosaic (MM) & + & - & - & - & 0.27 \\
\hline Mosaic (Mo) & + & - & - & - & 0.24 \\
\hline Mosaic \& Stunting (MoS) & + & - & - & - & 0.22 \\
\hline Shoe string & + & - & - & - & 0.24 \\
\hline Vein banding $(\mathrm{Vb})$ & + & - & - & - & 0.29 \\
\hline
\end{tabular}

+ Positive reaction, - Negative reaction.

Table 2. Pigment contents in chilli leaves infected with five biotypes of CMV.

\begin{tabular}{lccccc}
\hline $\begin{array}{l}\text { Symptom } \\
\text { type }\end{array}$ & $\begin{array}{c}\text { Chlorophyll-a } \\
(\mathrm{mg} / 100 \mathrm{~g} \\
\text { fresh wt.) }\end{array}$ & $\begin{array}{c}\text { Chlorophyll-b } \\
(\mathrm{mg} / 100 \mathrm{~g} \\
\text { fresh wt.) }\end{array}$ & $\begin{array}{c}\text { Total chlorophyll } \\
(\mathrm{mg} / 100 \mathrm{~g} \\
\text { fresh wt.) }\end{array}$ & Chl. a:b & $\begin{array}{c}\beta \text {-carotene } \\
(\mathrm{mg} / 100 \mathrm{~g} \\
\text { fresh wt.) }\end{array}$ \\
\hline $\mathrm{MM}$ & $51.79 \mathrm{~b}$ & $27.00 \mathrm{~b}$ & $78.79 \mathrm{~b}$ & $1.92 \mathrm{c}$ & $0.65 \mathrm{~b}$ \\
$\mathrm{Mo}$ & $31.30 \mathrm{e}$ & $15.55 \mathrm{e}$ & $46.85 \mathrm{e}$ & $2.01 \mathrm{~b}$ & $0.50 \mathrm{~d}$ \\
$\mathrm{MoS}$ & $28.94 \mathrm{f}$ & $13.53 \mathrm{f}$ & $41.84 \mathrm{f}$ & $2.14 \mathrm{a}$ & $0.41 \mathrm{e}$ \\
$\mathrm{SS}$ & $40.66 \mathrm{~d}$ & $20.77 \mathrm{~d}$ & $61.43 \mathrm{~d}$ & $1.96 \mathrm{bc}$ & $0.55 \mathrm{c}$ \\
$\mathrm{Vb}$ & $44.19 \mathrm{c}$ & $22.99 \mathrm{c}$ & $67.18 \mathrm{c}$ & $1.93 \mathrm{c}$ & $0.56 \mathrm{c}$ \\
$\mathrm{HL}$ & $69.58 \mathrm{a}$ & $44.12 \mathrm{a}$ & $113.70 \mathrm{a}$ & $1.58 \mathrm{~d}$ & $0.85 \mathrm{a}$ \\
$\mathrm{CV}$ & $3.21 \%$ & $4.11 \%$ & $3.33 \%$ & $2.67 \%$ & $3.97 \%$ \\
\hline
\end{tabular}

Means followed by same letter are not significantly different at $1 \%$ level by DMRT. MM - Mild mosaic, Mo Mosaic, MoS - Mosaic and Stunting, SS - Shoe string, Vb - Vein banding, HL - Healthy. 

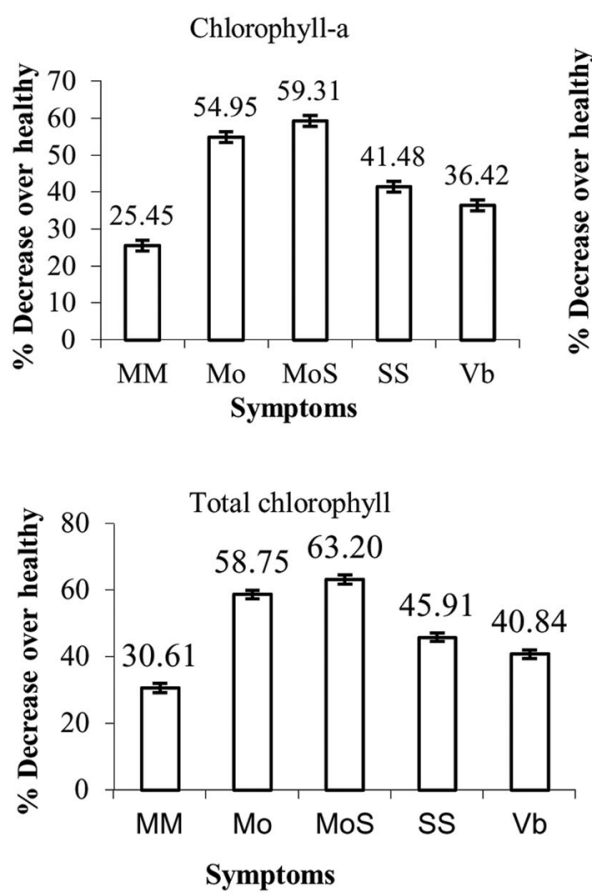

Chlorophyll b

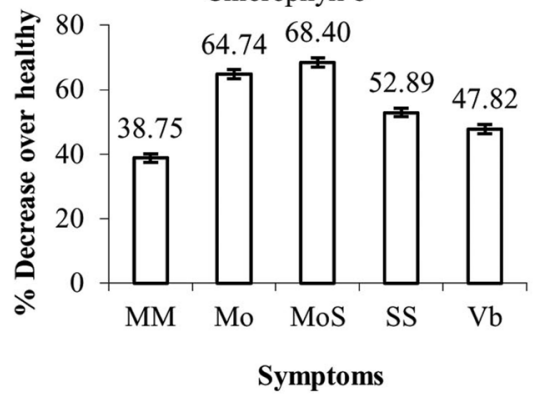

Chlorophyll a :b

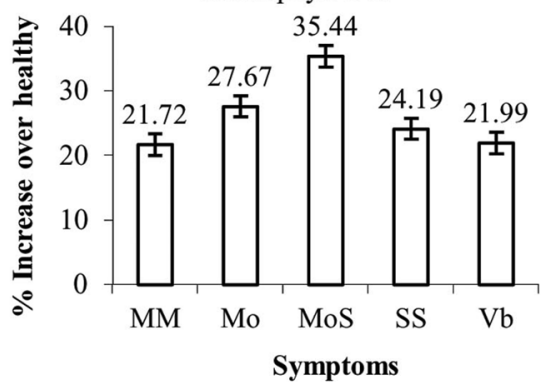

Fig. 2. Per cent change of pigment (chlorophyll-a, $b$, total chlorophyll and chlorophyll-a : $b$ ) in chilli leaves infected with five symptomatic isolate of CMV as compared to healthy. Mosaic and stunted exhibited highest chlorophyll reduction over healthy plants. Vertical bars indicate the LSD value at $1 \%$ level of significance. MM - Mild mosaic, Mo - Mosaic, MoS - Mosaic and Stunting, SS - Shoe string, Vb - Vein banding, HL - Healthy.

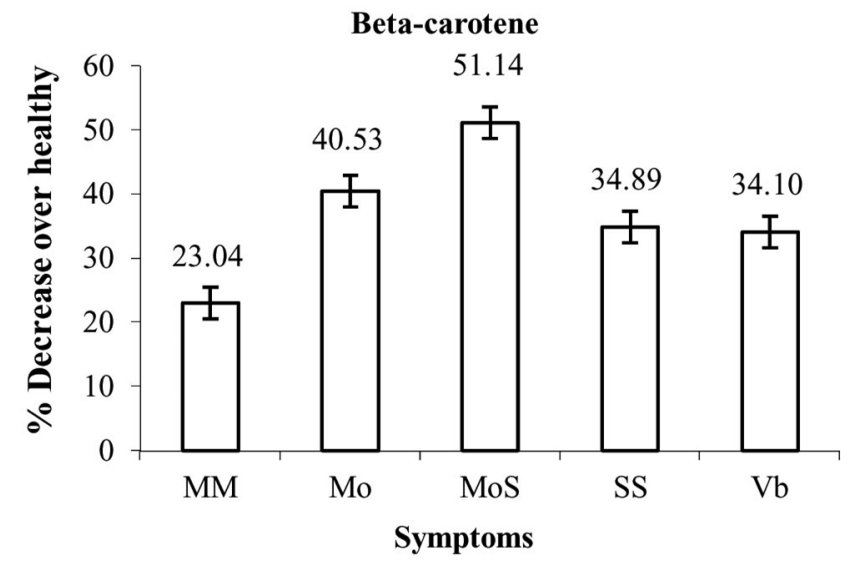

Fig. 3. Per cent reduction of $\beta$-carotene of chilli fruit infected with five symptomatic isolate of CMV as compared to healthy. Mosaic and stunted exhibited highest beta-carotene reduction over healthy plants. Vertical bars indicate the LSD value at $1 \%$ level of significance. MM - Mild mosaic, Mo - Mosaic, MoS Mosaic and stunting, SS - Shoe string, Vb - Vein banding, HL- Healthy. 
Table 3. Nucleic acid content in chilli leaves infected with different biotypes of CMV.

\begin{tabular}{lccc}
\hline $\begin{array}{l}\text { Symptom } \\
\text { type }\end{array}$ & \multicolumn{3}{c}{ Nucleic acid content } \\
\cline { 2 - 4 } & RNA mg/g & DNA mg/g & RNA : DNA \\
\hline MM & $13.95 \mathrm{~d}$ & $0.95 \mathrm{~b}$ & $14.68 \mathrm{~d}$ \\
Mo & $17.11 \mathrm{c}$ & $0.71 \mathrm{c}$ & $24.09 \mathrm{c}$ \\
$\mathrm{MoS}$ & $17.15 \mathrm{c}$ & $0.72 \mathrm{c}$ & $23.81 \mathrm{c}$ \\
$\mathrm{SS}$ & $19.43 \mathrm{a}$ & $0.59 \mathrm{~d}$ & $32.93 \mathrm{a}$ \\
$\mathrm{Vb}$ & $17.46 \mathrm{~b}$ & $0.70 \mathrm{c}$ & $24.94 \mathrm{~b}$ \\
$\mathrm{HL}$ & $12.26 \mathrm{e}$ & $1.07 \mathrm{a}$ & $11.46 \mathrm{e}$ \\
$\mathrm{CV}$ & $1.07 \%$ & $2.11 \%$ & $1.33 \%$ \\
\hline
\end{tabular}

Means followed by same letter did not significantly different at 1\% level by DMRT. MM - Mild mosaic, Mo - Mosaic, MoS - Mosaic and stunting, SS - Shoe string, Vb - Vein banding, HL- Healthy.

Table 4. Effects of five symptomatic isolate (biotype) of CMV on SPAD, photosynthesis rate, plant height, canopy and yield of chilli.

\begin{tabular}{lccccc}
\hline $\begin{array}{l}\text { Symptom } \\
\text { type }\end{array}$ & SPAD & $\begin{array}{c}\text { Photosynthetic } \\
\text { rate }\left(\mu \mathrm{mol} / \mathrm{m}^{2} / \mathrm{s}\right)\end{array}$ & $\begin{array}{c}\text { Plant height } \\
(\mathrm{cm})\end{array}$ & $\begin{array}{c}\text { Canopy } \\
(\mathrm{cm})\end{array}$ & $\begin{array}{c}\text { Yield } \\
(\mathrm{kg} / \mathrm{ha})\end{array}$ \\
\hline $\mathrm{MM}$ & $39.83 \mathrm{c}$ & $25.81 \mathrm{~b}$ & $37.43 \mathrm{~b}$ & $47.61 \mathrm{~b}$ & $7874.80 \mathrm{~b}$ \\
& $(-35.66)$ & $(-6.32)$ & $(-9.85)$ & $(-11.09)$ & $(-28.80)$ \\
$\mathrm{Mo}$ & $32.91 \mathrm{~d}$ & $23.41 \mathrm{c}$ & $35.04 \mathrm{bc}$ & $37.21 \mathrm{~d}$ & $4303.60 \mathrm{c}$ \\
& $(-46.84)$ & $(-15.03)$ & $(-15.61)$ & $(-30.51)$ & $(-61.09)$ \\
$\mathrm{MoS}$ & $30.43 \mathrm{e}$ & $22.84 \mathrm{c}$ & $23.63 \mathrm{e}$ & $25.37 \mathrm{f}$ & $2420.40 \mathrm{e}$ \\
& $(-50.85)$ & $(-17.10)$ & $(-43.09)$ & $(-52.62)$ & $(-78.11)$ \\
$\mathrm{SS}$ & $33.41 \mathrm{~d}$ & $22.98 \mathrm{c}$ & $31.61 \mathrm{~d}$ & $34.30 \mathrm{e}$ & $2809.20 \mathrm{~d}$ \\
& $(-46.03)$ & $(-16.59)$ & $(-23.87)$ & $(-35.95)$ & $(-74.60)$ \\
$\mathrm{Vb}$ & $45.39 \mathrm{~b}$ & $25.33 \mathrm{~b}$ & $33.73 \mathrm{~cd}$ & $41.25 \mathrm{c}$ & $4426.80 \mathrm{c}$ \\
& $(-26.68)$ & $(-8.06)$ & $(-18.76)$ & $(-22.97)$ & $(-59.97)$ \\
$\mathrm{HL}$ & $61.91 \mathrm{a}$ & $27.55 \mathrm{a}$ & $41.52 \mathrm{a}$ & $53.55 \mathrm{a}$ & $11069.60 \mathrm{a}$ \\
$\mathrm{CV}(\%)$ & 3.97 & 2.75 & 4.91 & 4.83 & 3.20 \\
\hline
\end{tabular}

Means followed by same letter did not vary significantly at $5 \%$ level by DMRT. Figures in the parentheses indicate per cent change over healthy plants. MM - Mild mosaic, Mo - Mosaic, MoS Mosaic and stunting, SS - Shoe string, Vb - Vein banding, HL - Healthy. 
The lower contents of DNA and higher contents of RNA were found in chilli leaves infected with five biotypes of CMV as compared to healthy (Table 3). The highest content of DNA was found in healthy leaves $(1.07 \mathrm{mg} / \mathrm{g})$ which was statistically different from leaves infected with five biotypes ( 0.59 to $0.95 \mathrm{mg} / \mathrm{g})$. RNA contents in the leaves were increased while that of DNA was decreased (Fig. 4). DNA and RNA content of healthy leaves was 1.07 and $12.26 \mathrm{mg} / \mathrm{g}$, respectively where RNA contents increased 13.72 to $58.48 \%$ in leaves infected with five biotypes of CMV as compared to healthy leaves. The highest content of RNA (19.43 mg/g) and lowest content of DNA $(0.59 \mathrm{mg} / \mathrm{g})$ was found in leaves infected with shoe string (SS). The highest reduction of DNA (44.48\%) was found in leaves infected with SS and the lowest (11.43\%) in MM. The highest increase of RNA was found $(58.48 \%)$ in leaves infected with SS and the lowest $(13.72 \%)$ in MM (Fig. 4). The ratio of RNA to DNA increased in the infected leaves and the highest 32.93 was found in SS and the lowest 11.46 in healthy (Table 3). The DNA and RNA ratio of other symptomatic isolates of CMV ranged 14.68 to 24.94. Similar results in Yellow vein mosaic virus (YVMV) infected leaves of country bean were reported by Hossain and Haider (1992). This might be due to enhanced activity of RNA synthesis and RNA polymerase after virus infection. These two enzymes are suggested to be responsible for higher RNA content. Lower content of DNA in infected leaves of country bean by YVMV and papaya by Papaya ring spot virus- papaya strain was also demonstrated by Hossain and Haider (1992) and Rahman et al. (2008). Based on findings of the present investigation, it may be concluded that the reduction of DNA content in leaf samples might be due to the breakdown or denaturation of nucleotides, the sub-structures of DNA (deoxyribose sugar molecules, nitrogenous bases and phosphate groups).

Table 5. Effects of five symptomatic isolate (biotype) of CMV on stomatal conductance, $\mathrm{CO}_{2}$ concentration and mesophyll conductance in chilli.

\begin{tabular}{lccc}
\hline $\begin{array}{l}\text { Symptom } \\
\text { type }\end{array}$ & $\begin{array}{c}\text { Stomatal conductance } \\
\left(\mu \mathrm{mol} / \mathrm{m}^{2} / \mathrm{s}\right)\end{array}$ & $\begin{array}{c}\text { Intercellular } \mathrm{CO}_{2} \\
(\mathrm{ppm})\end{array}$ & $\begin{array}{c}\text { Mesophyll conductance } \\
\left(\mu \mathrm{mol} / \mathrm{m}^{2} / \mathrm{s}\right)\end{array}$ \\
\hline $\mathrm{MM}$ & $0.323 \mathrm{a}$ & $218.45 \mathrm{a}$ & $0.118 \mathrm{a}$ \\
$\mathrm{Mo}$ & $0.180 \mathrm{~b}$ & $202.58 \mathrm{~b}$ & $0.116 \mathrm{a}$ \\
$\mathrm{MoS}$ & $0.169 \mathrm{~b}$ & $203.71 \mathrm{~b}$ & $0.113 \mathrm{a}$ \\
$\mathrm{SS}$ & $0.187 \mathrm{~b}$ & $196.72 \mathrm{c}$ & $0.116 \mathrm{a}$ \\
$\mathrm{Vb}$ & $0.190 \mathrm{~b}$ & $205.15 \mathrm{~b}$ & $0.123 \mathrm{a}$ \\
$\mathrm{HL}$ & $0.360 \mathrm{a}$ & $221.11 \mathrm{a}$ & $0.125 \mathrm{a}$ \\
\hline $\mathrm{CV}(\%)$ & 2.96 & 1.02 & 3.10 \\
\hline
\end{tabular}

Means followed by same letter did not vary significantly at 1\% level by DMRT. MM - Mild mosaic, Mo - Mosaic, MoS, Mosaic and stunted, SS - Shoe string, Vb - Vein banding, HL - Healthy. 
Changes in chlorophyll (SPAD), photosynthesis, growth and yield characters due to infection with five symptomatic isolate of CMV are presented in Table 4. Chlorophyll content (SPAD) and rate of photosynthesis showed significant variation in almost all cases. The MoS plants had the significantly lower amount of SPAD as compared to healthy and other symptomatic isolates. The highest SPAD value (61.91) and photosynthesis rate $\left(27.55 \mu \mathrm{mol} \mathrm{m} \mathrm{m}^{2} / \mathrm{s}\right)$ was found in healthy plants and the lowest SPAD (30.43) and photosynthesis rate $\left(22.84 \mu \mathrm{mol} \mathrm{m}^{2} / \mathrm{s}\right)$ was observed in MoS plants. Reduction of SPAD ranged 26.68 to $50.85 \%$ in CMV infected plants whereas photosynthesis rate varied from 6.32 to $17.10 \%$. The highest SPAD and photosynthesis rate reduction was observed in MoS plants and the lowest in MM. The variation in growth parameters like plant height and canopy spread and yield was considerable. The reduction in plant height and canopy spread was 43.09 and $52.62 \%$, respectively in MoS plants. Appreciable
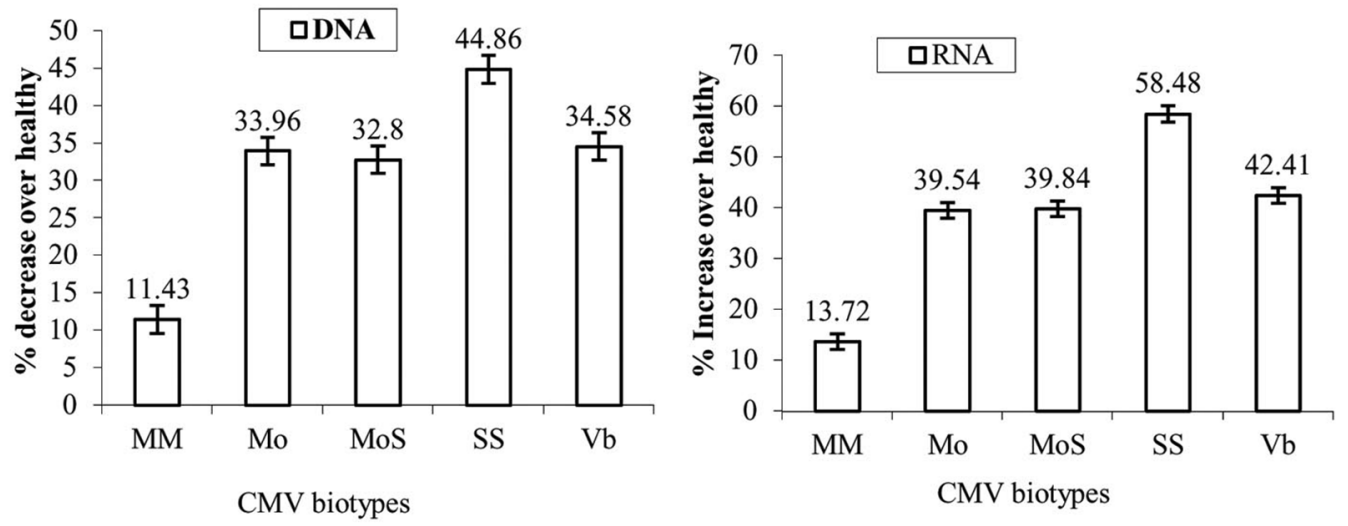

Fig. 4. Per cent change of nucleic acids (DNA, RNA) in chilli leaves infected with five symptomatic isolates of CMV as compared to healthy. Shoe string exhibited highest beta-carotene reduction over healthy plants. Vertical bars indicate the LSD value at $1 \%$ level of significance. MM - Mild mosaic, Mo - Mosaic, MoS Mosaic and Stunting, SS - Shoe string, Vb - Vein banding, HL - Healthy.

yield reduction was found in plants infected with five symptomatic isolate of CMV that ranged from 28.80 to $78.11 \%$. The highest yield reduction was found in plants infected with $\mathrm{MoS}(78.11 \%)$ and the lowest in MM (28.80 \%). Other physiological parameters like stomatal conductance $\left(0.360 \mu \mathrm{mol} \mathrm{m} \mathrm{m}^{2} / \mathrm{s}\right)$ and inter cellular $\mathrm{CO}_{2}(221.11 \mathrm{ppm})$ was observed high in healthy plants. Effect of other symptomatic isolates like Mo, MoS, SS and $\mathrm{Vb}$ on those parameters did not vary significantly. Mesophyll conductance did not vary significantly (Table 5). Results of the present investigation indicated that CMV causes changes in growth and physiological parameters which are responsible for yield reduction. Findings of the present study indicated that the host physiology changes due to infection with five symptomatic isolate of CMV that affect the growth and yield of chilli. The photosynthetic rate varied little bit among the five biotypes of CMV but appreciably varied with the healthy plants. Virus infected leaves are usually 
characterized by reduced photosynthetic rate (Goodman et al. 1986). Similar results were observed in the current experiment. In the present study photosynthetic rate was measured in per unit leaf area only but total or gross photosynthesis was not measured. Plant height and canopy spread was greatly reduced in the virus infected plants. Therefore, gross photosynthesis in the infected plants should have been very low. Most probably that was the reason for poor yield in the virus infected plants.

CMV caused considerable reduction of growth parameters as well as physiological parameters studied. The results indicated that yield reduction due to CMV is attributed to changes in host physiology which ultimately affect the growth parameters (plant height and canopy spread) of chilli.

Substantial crop loss is common with most of the viral diseases. The yield loss is, however, related with the severity of the symptoms (Bos 1976). Yield reduction of different crops, even when their vegetative organs are infected by virus, has been reported by Haider and Hossain (1994) and Alam et al. (1996). Levy and Marco (1982) reported the alteration of cellular component in potato tuber due to infection of Potato virus Y (PVY) and Potato leaf roll virus which ultimately affected the growth and yield of potato. Tajul et al. (2011) reported that Tomato yellow leaf curl virus alters the physicochemical constituents in tomato and reduced fruit number as well as fruit size that reduced the ultimate yield of tomato. The symptoms specificity and its severity are concerned with the changes of specific cellular components due to virus infection (Sreenivasulu et al. 1989).

The results of the present study revealed that CMV affects significantly on cellular components that altered the host physiology which reduced the ultimate yield of chilli. Further, yield loss is related with the alteration of the growth parameters that consequently associated with the severity and symptomatic isolate (biotypes) of CMV where mosaic and stunting, and shoe string appeared to be the most destructive.

\section{Acknowledgement}

The authors humbly express their gratitude to the Director General and Director Training and Communication, BARI, Joidebpur, Gazipur for providing financial and logistic support to conduct the investigation.

\section{References}

Alam N, Akanda AM and Khair A(1996) Biochemical changes of tomato due to purple vein virus. Bangladesh J. Bot. 25: 25-30.

Al-Musa A (1982) Incidence, economic importance and control of Tomato yellow leaf curl virus in Jordan. Plant Disease 66: 561-563.

Bos L (1976) Methods of studying plants as virus hosts. Method in Virology. pp. 129-162. Academic Press Inc., New York. 
Clark MF and Adams AN (1977) Characteristics of the micro plate method of ELISA for detection of plant viruses. J. Gen. Virol. 34: 475-483.

Esau K (1956) An anatomist's view of infected plants. American. J. Bot. 43: 739-748.

Fraser RSS (1987) Biochemistry of virus infected plants, 641 p. Research Studies Press Ltd. Letch Worth, Hertfordshire, England.

Fujisawa I, Hnanda T and Anang S (1986) Virus disease occurring on some vegetable crops in West Malaysia. Tropica Agricultural Research Report. Ministry of Agriculture, Forestry and Fisheries, Japan 20: 78-84.

Goodman RN, Kiraly Z and Wood KR (1986) The Biochemistry and Physiology of Plant Disease. University of Missouri Press, Columbia, USA.

Haider J and Hossain T (1994) Metabolic changes in okra (Abelmoschus esculentus (L.) Moench) caused by yellow mosaic virus. Bangladesh J. Bot. 16: 215-218.

Hossain T and Haider J (1992) Biochemical alteration in country bean due to yellow vein mosaic virus. Ann. Bangladesh Agri. 2(1): 13-16.

Kapoor P (2012) Detection of cucumber mosaic virus in bell pepper crop from Himachal Pradesh. Plant Dis. Res. 27 (1): 71-80.

Kim MK, Kwak RH, Lee SH, Kim JS, Kim KH, Cha BJ and Choi HS (2011) Characteristics of cucumber mosaic virus isolated from Zea mays in Korea. Plant Pathol. J. 27(4): 372-377.

Kubota F and Hamid A (1992) Comparative analysis of dry matter production and photosynthesis between mungbean (Vignaradiata L.) Wilczek and blackgram (V. mungo L. Hepper) grown in different light intensities. J. Fac. Agr. Kyushu Univ. 37(1-2): 71-80.

Levy D and Marco S (1982) The quality of seed tuber in the Golien Heights for spring season in Israel. Potato Res. 25: 107-1597.

Montasser MS, Tousignant ME and Kaper JM (1998) Viral satellite RNAs for the prevention of cucumber mosaic virus (CMV) disease in field-grown pepper and melon plants. Plant Dis. 82: 1298-1303.

Nagata MK, Dan and Yamashita I (1992) Simple method for simultaneous determination of chlorophyll and carotenoids in tomato. J. Japan. Soc. Hort. Sci. 61(2): 686-687.

Narayanasamy P and Palaniswami A (1973) Studies of yellow mosaic disease of soyabean. Effect of virus infection on plant pigments. Experimentia 29: 1166-1167.

Palukaitis P and Garcia-Arenal F (2003) "Cucumoviruses," Advances in Virus Research 62: 241323.

Palukaitis P, Roosinck MJ, Dietzgen RG and Francki RIB (1992) Cucumber mosaic virus. Adv. Virus Res. 41: 281-349.

Rahman H, Alam MM and Akanda AM (2008) Alteration of cellular nutritional elements and nucleic acids of papaya leaves infected with seven symptomatic isolates of PRSV-P. Inter. J. Agril. Res. 3: 219-226.

Spirin AS (1958) Quantitative analysis of nucleic acids by spectrophotometer. Biokhimia 25: 656662.

Sreenivasulu P and Nayudu MV (1989) Physiology of Virus Infected Plants. pp. 160-175. South Asian Publishers Pvt. Ltd., New Delhi, India.

Sreenivasulu P, Naidu RN and Naidu MV (1989) (Eds), p164 South Asian Publishers, New Delhi, India. 
Tajul MI, Naher K, Hossain T, Siddiqui Y and Sariah M (2011) Tomato yellow leaf curl virus (TYLCV) alters the phytochemical constituents in tomato fruits. Australian J. Crop Sci. 5(5): 575-581.

Witham FH Blaydes DF and Devlin RM (1986) Chlorophyll absorption spectrum and quantitative determination. In: Exercises in Plant Physiology. 2nd ed. Boaton. pp. 128-131.

Zitter TA and Murphy JF (2009) Cucumber mosaic virus. The Plant Health Instructor. DOI: 10.1094/PHI-I-2009-0518-01.

(Manuscript received on 03 July, 2019; revised on 17 July, 2019) 